\title{
CLINICAL AND BIOPSY FINDINGS IN TEMPORAL ARTERITIS
}

\author{
BY \\ A. T. BEVAN, M. S. DUNNILL, AND M. J. G. HARRISON \\ From the Department of the Regius Professor of Medicine \\ and the Department of Pathology, Radcliffe Infirmary, Oxford
}

Hutchinson (1890) described a man aged 80 years who was prevented from wearing his hat by painful, inflamed temporal arteries. Horton, Magath, and Brown (1932) described two more patients and called the syndrome temporal arteritis. Originally thought to be a localized, self-limiting, and benign disorder, inflammation of the temporal arteries is often part of a widespread arteritis (Cooke, Cloake, Govan, and Colbeck, 1946) which can cause blindness (Jennings, 1938) and death (Harrison, 1948).

The varied presentation of the disorder was emphasized by Paulley and Hughes (1960) and often the diagnosis is not made with certainty without histological examination of an affected artery. The histological appearances are also variable. The media is usually the site of collections of inflammatory cells and giant cells apparently related to fragmentation of the internal elastic lamina. Giant cells are not always found (Harrison, 1948; Paulley and Hughes, 1960) and in some cases intimal fibrosis predominates, with little evidence of cellular infiltration. In the face of a variable clinical picture and variable histology, we have studied 37 biopsied cases of temporal arteritis in an attempt to relate the clinical and histological features.

\section{Methods}

The medical records of all patients in the Radcliffe Infirmary thought to have been suffering from temporal arteritis in the period from 1945 to 1965 were reviewed. Those in whom biopsy of a superficial temporal artery had been carried out were selected for further study. This yielded 37 cases. Details of the symptoms, length of history, the clinical state of the arteries, and the laboratory investigations were extracted.

Independently one of us (M.S.D.), without knowledge of the clinical information, reviewed the biopsy sections.

\section{Results}

\section{Clinical Examination of the Temporal Arteries}

These were recorded as normal in appearance and to palpation in nine cases. In twenty cases the arteries were tender and, in addition, in five of these they were noted to be nodular or "beaded". In the remaining eight patients, although the vessels were not tender, there was reduction or absence of the normal pulsation.

\section{Histological Appearances}

Sections were taken at several different levels from each biopsy. They were stained with haematoxylin and eosin, by Masson's trichrome method, and by the Orcein method for demonstrating elastic tissue. It was possible to classify the biopsies into three broad groups: those showing giant cell arteritis, those showing arteritis but without giant cells, and those showing intimal fibrosis only.

(a) Giant cell arteritis (Fig. 1, overleaf).-Present in 23 cases. In these vessels the lumen of the artery frequently showed obliteration or gross distortion because of the presence of fibrous tissue. Thrombosis was not present. The striking features were the presence of very plump fibroblasts and the large quantity of metachromatic material, seen in Azure A preparations, surrounding them. Evidence of recanalization with the formation of numerous new vascular channels, occasionally possessing smooth muscle in their walls, was also present. In some of the sections haemosiderin could be seen. In this portion of the artery the inflammatory cellular infiltrate was concentrated near the internal elastic lamina or its remains. It consisted most commonly of lymphocytes but occasionally included neutrophil polymorphonuclear leucocytes and eosinophils. The giant cells were invariably of the Langhans variety with peripherally-placed nuclei, and they were always present in the region of a break in the 


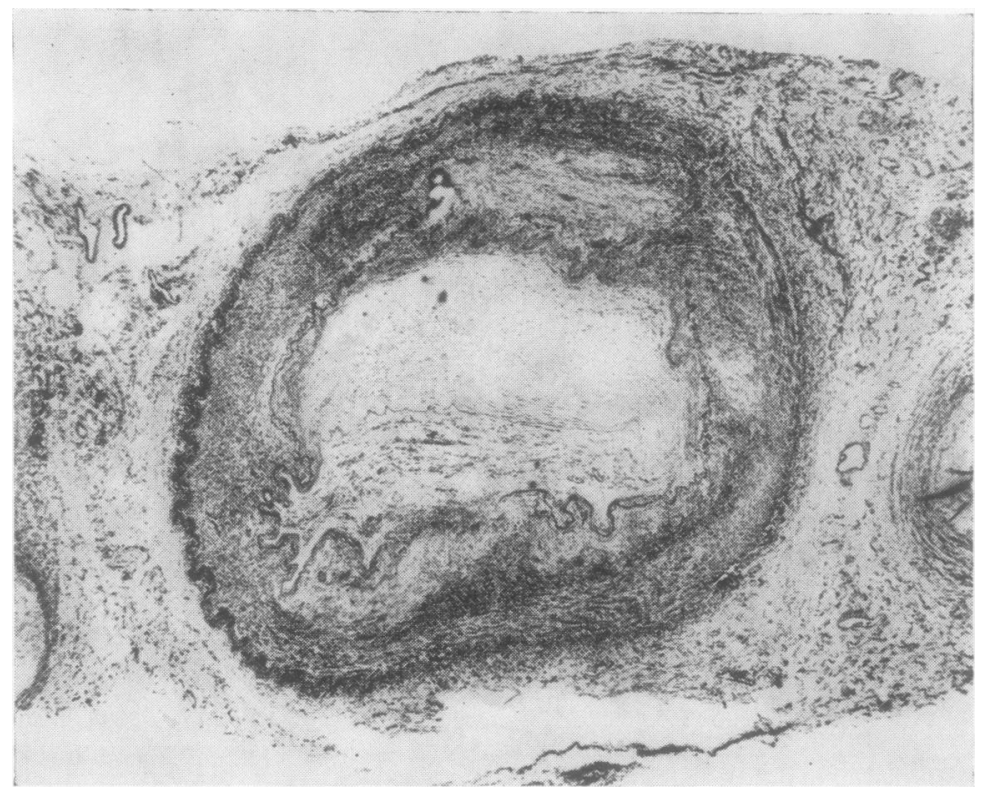

Fig. 1(a).-Section of temporal artery, showing obliteration of lumen with fibrous tissue and some attempt at recanalization.

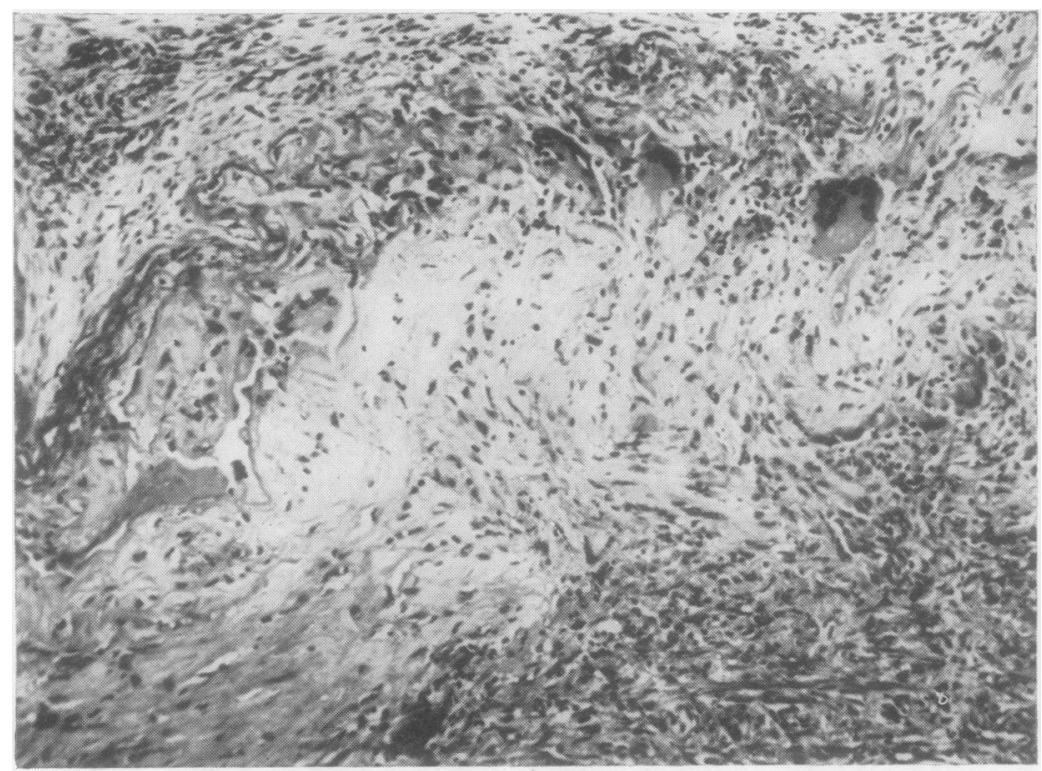

Fig. 1(b).-High-power view of portion of the arterial wall seen in

Fig. $1 a$, showing giant cells related to point of interruption of elastic lamina.

internal elastic lamina. They were most frequently situated in the outermost part of the fibrosed intima. Their derivation is uncertain but there is some slight tinctorial evidence, seen particularly in the trichrome stains, that they may possibly be derived from smooth muscle cells. The media often showed rather striking preservation and where smooth muscle was seen there was little or no cellular $\stackrel{\mathbb{D}}{?}$ infiltration. Focal breaches occurred in the media adjacent to a break in the internal elastic lamina, and at this point giant cells and lymphocytes could $\overrightarrow{\mathbb{D}}$ be seen. The adventitia occasionally showed $a \stackrel{\frac{}{\odot}}{\circ}$ giant cell infiltration but most commonly exhibited a generalized infiltration with lymphocytes. 
(b) Arteritis without giant cells (Fig. 2).-Because of the focal nature of the disease, considerable caution must be observed in claiming that giant cells are absent in any case of temporal arteritis. However, in five cases they were not seen in sections taken at several different levels and in general these showed a rather more acute infiltration with more neutrophil polymorphonuclear leucocytes and eosinophils than in the first group. In one of these cases thrombus was seen in the lumen.

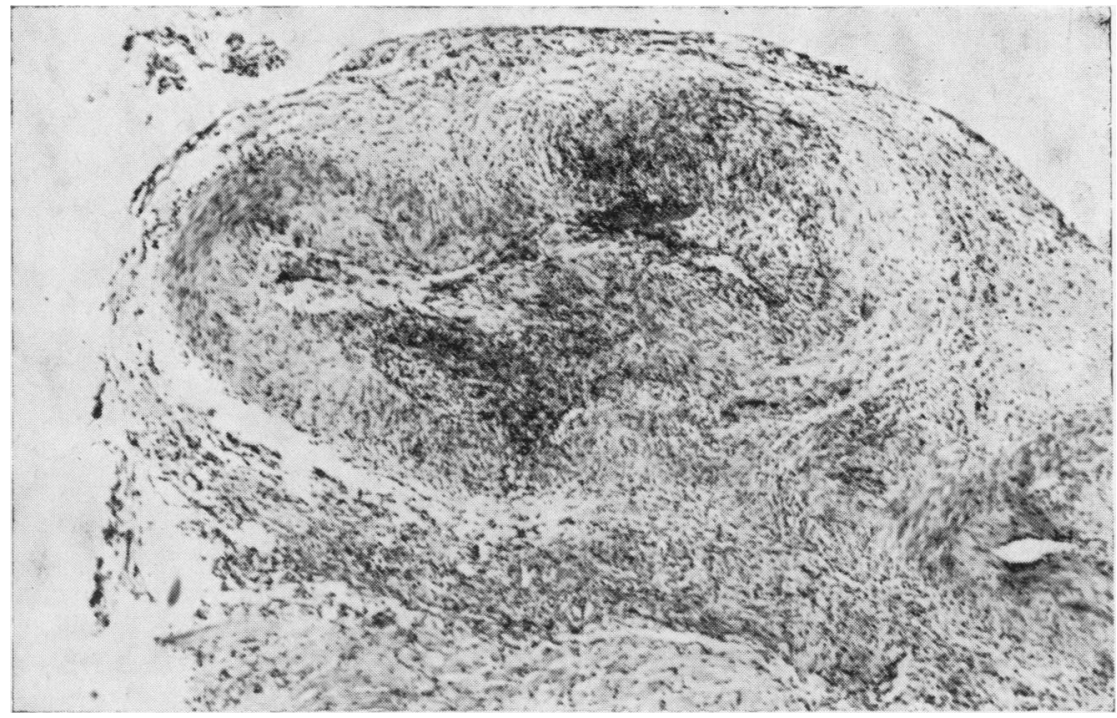

Fig. 2(a).-Temporal artery, showing severe arteritis with no giant cells.

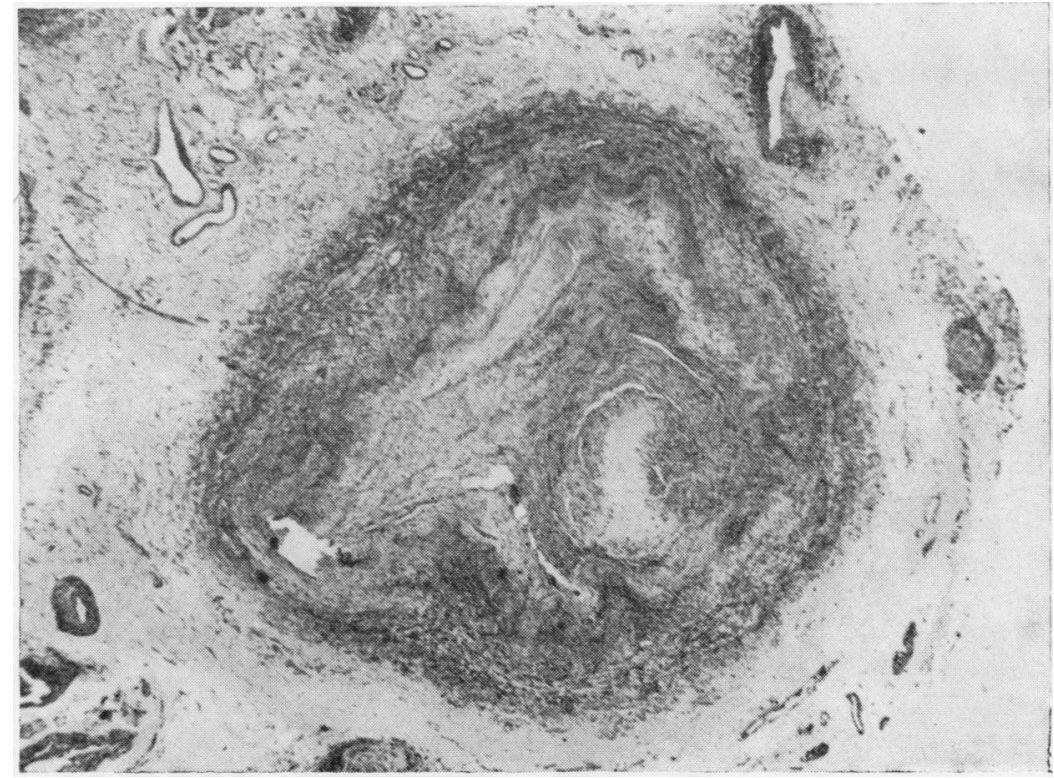

Fig. 2(b).-Arteritis with no giant cells. (Haematoxylin and eosin 


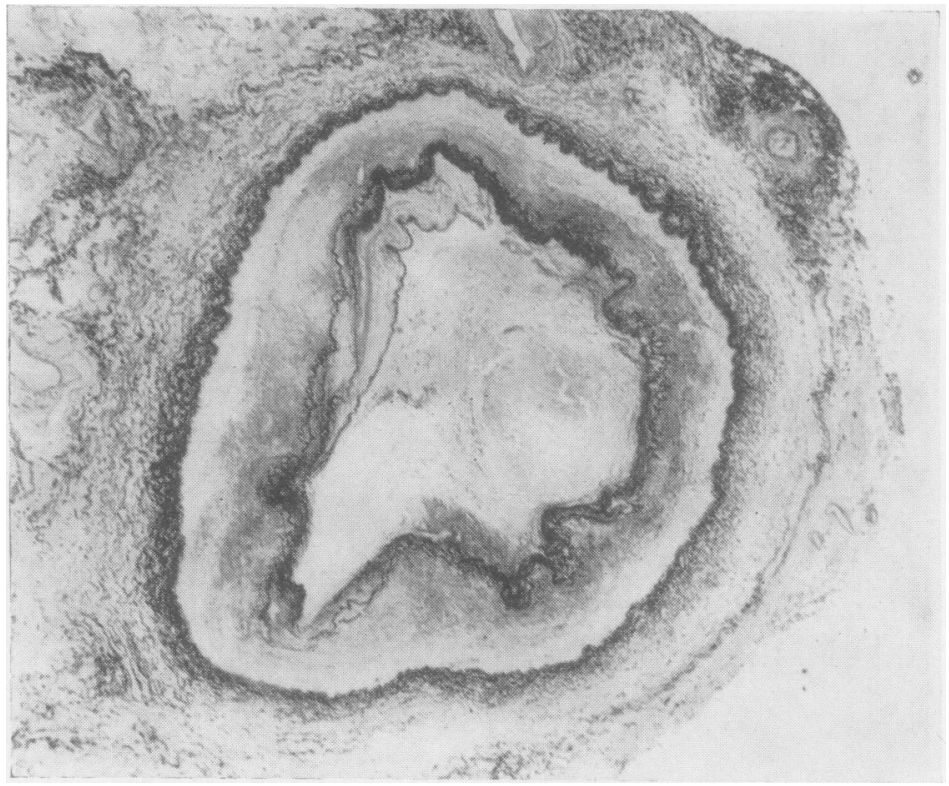

Fig. 2(c).-Arteritis with no giant cells (Verhoeff and van Gieson).

(c) Intimal fibrosis (Fig. 3).--In nine arteries the predominant finding was the presence of intimal fibrosis. The fibrous tissue was in most cases rather acellular and there did not appear to be an excess of metachromatic material.
The internal elastic lamina in these vessels was for $\square$ the most part intact, though an occasional small breach could be seen. The media was essentially normal but the adventitia occasionally showed focal $\cong$ lymphocytic aggregates.
Fig. 3.-Temporal artery showing intimal fibrosis only.

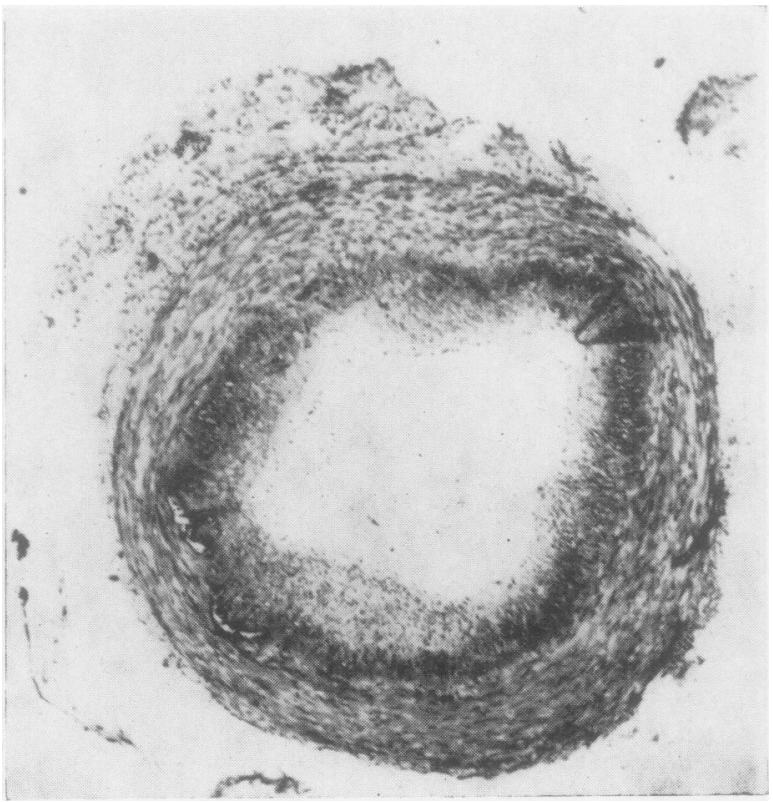




\section{Relationship between Clinical and}

\section{Pathological Features}

Table I sets out the clinical and laboratory features of the cases according to their subdivision into three groups on the basis of histological appearances. There is no evidence that length of history, erythrocyte sedimentation rate, or other feature is strongly linked with any particular histological picture. The biopsies showing a "burnt-out" arteritis with marked intimal fibrosis did not prove to have come from patients with longer histories, less systemic upset, or lower erythrocyte sedimentation rates.

TABLE I

CORRELATION OF CLINICAL AND BIOPSY FEATURES OF 37 CASES OF TEMPORAL ARTERITIS

\begin{tabular}{|c|c|c|c|c|}
\hline \multirow{2}{*}{\multicolumn{2}{|c|}{ Clinical Features }} & \multicolumn{3}{|c|}{ Histological Type } \\
\hline & & Arteritis & $\begin{array}{l}\text { Giant } \\
\text { Cells }\end{array}$ & $\begin{array}{l}\text { Intimal } \\
\text { Fibrosis }\end{array}$ \\
\hline \multicolumn{2}{|c|}{$\begin{array}{l}\text { No. of Cases } \\
\text { Mean Age (yrs) }\end{array}$} & $\begin{array}{r}5 \\
72\end{array}$ & $\begin{array}{l}23 \\
70\end{array}$ & $\begin{array}{r}9 \\
69\end{array}$ \\
\hline Sex & $\begin{array}{l}\text { Female } \\
\text { Male }\end{array}$ & 5 & $\begin{array}{r}16 \\
7\end{array}$ & $\begin{array}{l}6 \\
3\end{array}$ \\
\hline \multicolumn{2}{|c|}{ Length of History (mths) } & 9 & 5 & 5 \\
\hline $\begin{array}{l}\text { Signs } \\
\text { and } \\
\text { Symptoms } \\
\text { (per cent.) }\end{array}$ & $\begin{array}{l}\text { Headache } \\
\text { Malaise } \\
\text { Weight loss } \\
\text { Anorexia } \\
\text { Visual loss } \\
\text { Fever }\end{array}$ & $\begin{array}{r}100(5) \\
40(2) \\
60(3) \\
40(2) \\
20(1) \\
80(4)\end{array}$ & $\begin{array}{r}100(23) \\
48(1) \\
48(11) \\
44(10) \\
26(16) \\
61(14)\end{array}$ & $\begin{array}{r}100(9) \\
44(4) \\
56(5) \\
56(5) \\
44(4) \\
22(2)\end{array}$ \\
\hline \multicolumn{2}{|c|}{$\begin{array}{l}\text { Mean Erythrocyte Sedimenta- } \\
\text { tion Rate (mm./hr) } \\
\text { White Blood Cell Count }\end{array}$} & $\begin{array}{r}94 \\
10,000\end{array}$ & $\begin{array}{r}78 \\
10,000\end{array}$ & $\begin{array}{r}95 \\
8,000\end{array}$ \\
\hline
\end{tabular}

Table II relates the clinical state of the temporal arteries at the time of biopsy with the histological appearance of the specimen. The important finding is that a vessel which is clinically normal in all respects may nevertheless yield evidence of an arteritis (5/9) and may contain giant cells (4/9).

TABLE II

COMPARISON BETWEEN THE CLINICAL STATE OF THE TEMPORAL ARTERY AND THE BIOPSY FINDINGS

\begin{tabular}{|c|c|c|c|c|}
\hline \multirow{2}{*}{$\begin{array}{l}\text { Clinical State } \\
\text { of the Artery }\end{array}$} & \multirow{2}{*}{$\begin{array}{l}\text { No. of } \\
\text { Cases }\end{array}$} & \multicolumn{3}{|c|}{ Histology } \\
\hline & & Arteritis & $\begin{array}{c}\text { Giant } \\
\text { Cells }\end{array}$ & $\begin{array}{l}\text { Intimal } \\
\text { Fibrosis }\end{array}$ \\
\hline $\begin{array}{l}\text { Normal } \\
\text { Tender } \\
\text { Loss of Pulsation }\end{array}$ & $\begin{array}{r}9 \\
20 \\
8\end{array}$ & $\begin{array}{l}1 \\
4 \\
-\end{array}$ & $\begin{array}{r}4 \\
13 \\
6\end{array}$ & $\begin{array}{l}4 \\
3 \\
2\end{array}$ \\
\hline
\end{tabular}

One patient was re-biopsied on two further occasions. In all three instances the artery was tender when biopsied. In one of the biopsy specimens there was evidence of an arteritis. The other specimens showed intimal fibrosis.

Deterioration of vision was noted by eleven patients and in Table III the clinical and pathological information on these patients is compared with that of those who had no such complications. No clear differences emerge which might be related to the pathogenesis of the ocular involvement or used to predict it. It was noteworthy that two of the patients with ocular involvement had clinically normal temporal arteries.

TABLE III

COMPARISON OF CASES WITH AND WITHOUT OCULAR INVOLVEMENT

\begin{tabular}{|c|c|c|c|}
\hline \multicolumn{2}{|c|}{ Clinical Features } & $\begin{array}{c}\text { No Eye } \\
\text { Involvement }\end{array}$ & $\begin{array}{c}\text { Eye } \\
\text { Involvement }\end{array}$ \\
\hline \multicolumn{2}{|c|}{$\begin{array}{l}\text { No. of Cases } \\
\text { Mean Age (yrs) }\end{array}$} & $\begin{array}{l}26 \\
74\end{array}$ & $\begin{array}{l}11 \\
76\end{array}$ \\
\hline Sex & $\begin{array}{l}\text { Male } \\
\text { Female }\end{array}$ & $\begin{array}{r}7 \\
19\end{array}$ & $\begin{array}{l}4 \\
7\end{array}$ \\
\hline \multicolumn{2}{|c|}{ Length of History (mths) } & 6 & 5 \\
\hline $\begin{array}{l}\text { Signs } \\
\text { and } \\
\text { Symptoms } \\
\text { (per cent.) }\end{array}$ & $\begin{array}{l}\text { Headache } \\
\text { Malaise } \\
\text { Weight loss } \\
\text { Anorexia } \\
\text { Muscle pain } \\
\text { Joint pain } \\
\text { Jaw pain } \\
\text { Fever }\end{array}$ & $\begin{array}{r}100 \\
50 \\
50 \\
50 \\
46 \\
15 \\
23 \\
54\end{array}$ & $\begin{array}{r}100 \\
27 \\
55 \\
27 \\
18 \\
36 \\
36 \\
55\end{array}$ \\
\hline \multicolumn{2}{|c|}{$\begin{array}{l}\text { Mean Hb (g./per cent.) } \\
\text { Erythrocyte Sedimentation Rate } \\
\text { (mm./hr) } \\
\text { White Blood Cell Count }\end{array}$} & $\begin{array}{l}11 \cdot 2 \\
90 \\
10,000\end{array}$ & $\begin{array}{c}11 \cdot 4 \\
83 \\
10,000\end{array}$ \\
\hline $\begin{array}{l}\text { Temporal } \\
\text { Artery } \\
\text { (per cent.) }\end{array}$ & $\begin{array}{l}\text { Tender } \\
\text { Loss of pulse } \\
\text { Normal }\end{array}$ & $\begin{array}{l}54 \\
20 \\
27\end{array}$ & $\begin{array}{l}55 \\
27 \\
18\end{array}$ \\
\hline $\begin{array}{l}\text { Biopsy } \\
\text { (per cent.) }\end{array}$ & $\begin{array}{l}\text { Arteritis } \\
\text { Giant cells } \\
\text { Intimal fibrosis }\end{array}$ & $\begin{array}{l}15 \\
65 \\
20\end{array}$ & $\begin{array}{r}9 \\
55 \\
36\end{array}$ \\
\hline
\end{tabular}

\section{Discussion}

In all of the present cases the biopsy sections were thought to confirm the clinical diagnosis of temporal (giant cell) arteritis. Much has been written about the difficulty of distinguishing temporal arteritis from polyarteritis nodosa on histological grounds (Jennings, 1938; Harrison, 1948; Ross Russell, 1959). There is usually little difficulty if the clinical picture is considered together with the histological evidence (Harrison, 1948). Although giant cell arteritis has been seen at autopsy to involve nearly all medium and large sized arteries (Cooke and others, 1946; Harrison, 1948; Ross Russell, 1959), clinical evidence of the involvement of visceral vessels is rare (Ross Russell, 1959). Renal involvement has never been described clinically although the renal artery has been found to be affected at autopsy (Sproul, 1942). The clinical predominance of symptoms related to cranial vessels despite the widespread nature of the disease remains unexplained.

Nine of the 37 patients had no detectable clinical abnormality of the superficial temporal arteries despite having headache and biopsy involvement of these vessels. Miller Fisher (1961) has claimed that 
minor abnormalities of the vessels can always be detected by palpation in such circumstances, and that furthermore careful palpation is as reliable as arterial biopsy in making a confident early diagnosis. Most physicians do not find this so and one in four of the cases biopsied at this hospital have had apparently normal temporal arteries. It is of great interest that these vessels were nevertheless productive of the same histological pattern as were tender, nodular, occluded vessels. Positive biopsies have also been obtained from clinically normal vessels in cases of polymyalgia rheumatica (Alestig and Barr, 1963), which itself may develop into temporal arteritis (Harrison and Bevan, 1967). Hollenhorst, Brown, Wagener, and Shick (1960) mentioned that they obtained diagnostic biopsies from apparently normal vessels but they did not say how often this situation arose and the point has received little attention. As early diagnosis is so vital in the anticipation of ocular complications, it is important to realise a clinically normal artery may yield a positive biopsy.

The biopsy findings reported here fell into three groups, one showing the features of an arteritis with marked cellular infiltration, the second and largest group containing evidence of an arteritis together with multi-nucleate giant cells, and the third showing little cellular infiltration but striking intimal fibrosis. It was thought that these three subgroups might have represented acute, subacute, and chronic stages of the arteritis, but this was not supported by the study of the clinical features of the cases. Intimal fibrosis was the predominating feature of the biopsy of several acute florid cases. Harrison, Harrison, and Kopelman (1955) re-biopsied two cases of temporal arteritis after starting steroid treatment. The earlier biopsies had shown giant cells and marked lymphocytic infiltration; after treatment both showed intimal fibrosis. Harrison and others concluded that intimal fibrosis represented an inactive phase of the disease and that its presence in a biopsy could be used to assess progress and even to guide the dosage of steroid. Our findings do not support that contention. Rather the finding of intimal fibrosis can be considered to carry the same significance as the finding of giant cells. It is not $\frac{\mathrm{O}}{\mathrm{N}}$ known why the histological picture is so variable. The vessel is often involved in a focal manner $\stackrel{\vec{S}}{\vec{S}}$ (Harrison, 1948) and it is possible that in some cases $\overline{0}$ an insufficient length of the artery was biopsied, though in fact 10 to $15 \mathrm{~mm}$. were taken in each case. The failure to find giant cells in each case may be due to the patchy involvement of the vessel and this view would receive indirect support from our patient who had three biopsies. On each. occasion the vessel was tender and the erythrocyte sedimentation rate elevated. On two occasions the sections showed intimal fibrosis and on the other a cellular "arteritis".

Visual failure continues to occur in 30 to 50 per. cent. of cases (Harrison, 1948; Roux, 1954; Ross Russell, 1959; Hollenhorst and others, 1960; ป present series). This that suggests our ability to $\circ$ anticipate its appearance has not improved greatly. The eleven cases with partial or complete loss of $\bar{z}$ vision in this series were studied from both the clinical and the pathological standpoint. Nothing $\vec{\oplus}$ appeared to demarcate them from those who did not suffer this complication. There is thus as yet no way of predicting which cases may develop visual failure. It is important to note that in two of the eleven cases the temporal arteries appeared entirely normal on clinical examination.

\section{Summary}

The clinical features of 37 cases of temporal arteritis were compared with the histological appearance of their arterial biopsies. One in four of the cases had clinically normal temporal arteries, but these yielded the same microscopical evidence of $\dot{0}$ a giant cell arteritis as did tender, nodular, occluded vessels. Eleven patients with visual failure did not $ᄋ$ appear to differ clinically or histologically from those without ocular involvement. The different $\frac{9}{7}$ histological appearances obtained on arterial biopsy $\rightarrow$ are discussed. It is stressed that the finding of clinically normal temporal arteries does not rule out the diagnosis of temporal arteritis.

\section{REFERENCES}

Alestig, K., and Barr, J. (1963). Lancet, 1, 1228 (Giant-cell arteritis: A biopsy study of polymyalgia rheumatica, including one case of Takayasu's disease).

Cooke, W. T., Cloake, P. C. P., Govan, A. D. T., and Colbeck, J. C. (1946). Quart. J. Med., 15, 47 (Temporal arteritis: a generalized vascular disease).

Fisher, C. Miller (1961). Amer. med. Ass., 175, 325 (Palpation of arteries in temporal arteritis; re-emphasis of the value of careful palpation). 
Harrison, C. V. (1948). J. clin. Path., 1, 197 (Giant-cell or temporal arteritis: a review).

Harrison, M. J. G., and Bevan, A. T. (1967). Lancet, 2, 638 (Early symptoms of temporal arteritis).

Harrison, R. J., Harrison, C. V., and Kopelman, H. (1955). Brit. med. J., 2, 1593 (Giant-cell arteritis with aneurysms: effects of hormone therapy).

Hollenhorst, R. W., Brown, J. R., Wagener, H. P., and Shick, R. M. (1960). Neurology, 10, 490 (Neurologic aspects of temporal arteritis).

Horton, B. T., Magath, T. B., and Brown, G. E. (1932). Proc. Mayo Clin., 7, 700 (An undescribed form of arteritis of the temporal vessels).

Hutchinson, J. (1890). Arch. Surg. (London), 1, 323 (Diseases of the arteries).

Jennings, G. H. (1938). Lancet, 1, 424 (Arteritis of the temporal vessels).

Paulley, J. W., and Hughes, J. P. (1960). Brit. med. J., 2, 1562 (Giant-cell arteritis, or arteritis of the aged).

Roux, J. L. (1954). Helv. med. Acta, Suppl. 34 (Le syndrome de l'artérite temporale).

Russell, R. W. Ross (1959). Quart. J. Med., 28, 471 (Giant-cell arteritis: a review of 35 cases).

Sproul, E. E. (1942). N.Y.St. J. Med., 42, 345 (A case of "temporal arteritis").

\section{Résultats de l'examen clinique et des biopsies dans 37 cas d'artérite temporale}

\section{RÉSUMÉ}

On a comparé les signes cliniques de 37 cas d'artérite temporale avec l'aspect histologique de leurs biopsies artérielles. Dans un cas sur quatre les artères temporales étaient cliniquement normales mais à l'examen histologique on y trouva les mêmes signes d'artérite à cellules géantes que dans les vaisseaux douloureux, noduleux et obstrués. Onze malades ayant des troubles visuels ne paraissaient pas différer cliniquement ou histologiquement de ceux qui n'avaient pas d'atteinte oculaire. On discute les différents aspects histologiques observés dans les biopsies artérielles. On souligne que le fait de trouver des artères temporales cliniquement normales ne permet pas d'exclure l'artérite temporale.

\section{Hallazgos clínicos y de biopsia en 37 casos de arteritis temporal}

\section{Sumario}

Se compararon los rasgos clínicos de 37 casos de arteritis temporal con el aspecto histológico de sus biopsias arteriales. En una cuarta parte de los casos las arterias temporales fueron clínicamente normales, pero histológicamente presentaron el cuadro de arteritis con células gigantes similar al encontrado en los vasos doloridos, nodulares y ocluidos. Once enfermos con disturbios visuales no parecieron diferir clínicamente o histológicamente de los sin afección ocular. Se discuten las diferentes apariencias histológicas observadas en biopsias arteriales. Se destaca el hecho de que la normalidad clínica de arterias temporales no excluye la existencia de una arteritis temporal. 